\title{
Karakteristik Pengembangan Wilayah Sebelum dan Sesudah Pemekaran Kabupaten Jayapura
}

\author{
Agustinus Kaeng Udiarto ${ }^{1}$ \\ Magister Pembangunan Wilayah dan Kota \\ Fakultas Teknik, Universitas Diponegoro, Semarang, Indonesia
}

Artikel Masuk : 11 Juni 2015

Artikel Diterima : 7 Agustus 2015

Tersedia Online : 31 Agustus 2015

\begin{abstract}
Abstrak: Isu pengembangan wilayah di Jayapura tidak dapat dipisahkan dari isu pemekaran wilayah. Pemekaran wilayah di Kabupaten Jayapura diharapkan mampu menciptakan lapangan pekerjaan, mengurangi tingkat kemiskinan, meningkatkan ketersediaan infrastruktur yang memadai, memeratakan persebaran penduduk, dan mempercepat proses pengembangan wilayah. Penelitian ini bertujuan untuk mengetahui perkembangan wilayah di Kabupaten Jayapura sebelum dan setelah pemekaran, dengan rentang waktu antara tahun 2002 hingga 2012. Analisis dibatasi pada aspek ekonomi, sosial kependudukan dan infrastruktur. Penelitian menggunakan metode kuantitatif melalui teknik analisis komparasi. Hasil penelitian menunjukkan bahwa Kabupaten Jayapura belum cukup berhasil mengalami perkembangan setelah pemekaran wilayah. Pengembangan wilayah Kabupaten Jayapura belum memberikan pengaruh signifikan bagi aspek ekonomi dan sosial kependudukan karena angka pengangguran dan rasio guru terhadap murid yang memiliki kecenderungan negatif. Namun, aspek infrastruktur telah berdampak positif bagi pengembangan wilayah ditandai dengan peningkatan jumlah dan kondisi infrastruktur terutama sarana pendidikan dan kesehatan. Untuk itu, dapat disimpulkan bahwa pengembangan wilayah dapat berhasil apabila terjadi kecenderungan positif aspek ekonomi, sosial kependudukan, dan infrastruktur.
\end{abstract}

Kata Kunci: aspek ekonomi, aspek infrastruktur, aspek sosial kependudukan, pemekaran wilayah, pengembangan wilayah

\begin{abstract}
The regional development issue in Jayapura cannot be separated from the issue of regional split. The regional split in Jayapura District is expected to generate job opportunity, to reduce poverty, to improve the availability of adequate infrastructures, to equalize the distribution of population, and to accelerate the regional development process. This study aims to determine the development of Jayapura District before and after the regional split between 2002 and 2012. The analysis is limited to economic, social, demographic and infrastructures aspects. The study is conducted by using a quantitative method through comparative analysis. The results show that the Jayapura District has not quite successfully to develop after the regional split happened. The regional development of Jayapura District has not significantly influenced the economic and social demographic aspects since the unemployment rate, and the ratio of teachers to students have a negative tendency. However, the infrastructure aspect has a positive impact on the regional development characterized by
\end{abstract}

\footnotetext{
${ }^{1}$ Korespondensi Penulis: Program Studi Magister Pembangunan Wilayah dan Kota, Fakultas Teknik, Universitas Diponegoro Email: agustinuskaeng87@gmail.com
} 
the increasing number of and condition of infrastructures, especially education and health facilities. Therefore, it can be concluded that the development of the region can be successful if there is a positive trend of economic, social demographic, and infrastructure aspects.

Keywords: economic aspect, infrastructure aspect, social demographic aspect, regional split, regional development

\section{Pendahuluan}

Provinsi Papua memiliki potensi yang sangat besar dalam bidang ekonomi dan memiliki sumber daya alam yang melimpah. Namun, kondisi geografis yang tidak mendukung menjadi salah satu kendala daerah ini untuk dikembangkan dengan cepat. Limitasi kondisi geografis menyebabkan terjadinya ketimpangan pembangunan wilayah yang cukup besar karena terjadi aglomerasi/pemusatan kegiatan ekonomi di Kota Jayapura sebelum terjadinya pemekaran wilayah.

Pada prinsipnya, pemekaran wilayah dilakukan untuk mengoptimalkan jangkauan pelayanan kepada masyarakat (Rasyid, 2007). Lebih jauh, pemekaran wilayah kabupaten/kota menjadi beberapa kabupaten/kota baru pada dasarnya merupakan upaya meningkatkan kualitas dan intensitas pelayanan pada masyarakat (Khairullah \& Cahyadin, 2006). Pemekaran wilayah bertujuan untuk memperpendek rentang kendali pemerintahan, membuka ketimpangan-ketimpangan pembangunan wilayah dan menciptakan perekonomian wilayah yang kuat demi tercapainya kesejahteraan masyarakat, sehingga pemekaran wilayah diharapkan dapat mendekatkan pelayanan kepada masyarakat, membuka peluang baru bagi upaya pemberdayaan masyarakat dan meningkatkan intensitas pembangunan guna mensejahterakan masyarakat. Namun, lebih jauh, pemekaran wilayah dapat memunculkan konflik keruangan apabila tidak disertai dengan batas sistem wilayah pembangunan yang jelas (Harmantyo, 2007).

Fenomena pemekaran wilayah di Papua setelah pemerintahan orde baru hingga memasuki pemerintahan saat ini menarik untuk ditelaah secara mendalam. Isu pemekaran wilayah terutama di Papua selalu disertai dengan isu-isu seputar reformasi, demokratisasi, HAM (Hak Asasi Manusia) dan keadilan sosial. Khairullah dan Cahyadin (2006) menyatakan bahwa pemekaran wilayah kabupaten baru pada dasarnya dilakukan sebagai upaya meningkatkan kualitas dan intensitas pelayanan pada masyarakat. Faktor-faktor lain yang memicu terjadinya pemekaran wilayah antara lain perbedaan agama, perbedaan etnis dan budaya, ketimpangan pembangunan ekonomi antar daerah, serta luas daerah. Hal ini didukung dengan pernyataan Ventauli (2009) bahwa perbedaan agama merupakan salah satu unsur yang dapat menyebabkan timbulnya keinginan masyarakat untuk memisahkan diri dari suatu negara/daerah yang telah ada untuk menjadi negara/daerah baru, perbedaan etnis dan budaya juga merupakan unsur penting lainnya yang dapat memicu terjadinya keinginan untuk melakukan pemekaran wilayah. Ketimpangan pembangunan ekonomi antar daerah ini selanjutnya mendorong terjadinya kecemburuan sosial dan merasa dianaktirikan oleh pemerintah pusat sehingga akhirnya muncul keinginan untuk melakukan pemekaran wilayah, selain itu wilayah yang besar akan cenderung menyebabkan pelayanan publik tidak dapat dilakukan secara efektif dan merata ke seluruh pelosok daerah. Lebih lanjut, menurut World Bank (2001) ada empat faktor pendorong adanya pemekaran wilayah di era pasca reformasi, yaitu: 1) Motif untuk efektivitas/efisiensi administrasi pemerintahan mengingat wilayah daerah yang begitu luas, penduduk yang menyebar dan ketertinggalan pembangunan; 2) kecenderungan untuk homogenitas (etnis, bahasa, agama, urban-rural, tingkat pendapatan,dan lain-lain); 3) adanya kemajuan fiskal yang dijamin oleh undang-undang (disediakan Dana Alokasi Umum/DAU, bagi hasil dari 
sumber daya alam dan disediakannya sumber-sumber Pendapatan Asli Daerah/PAD); 4) motif pemburu rente (bureaucratic a political rent-seeking) para elit.

Sejalan dengan adanya isu pemekaran wilayah di Provinsi Papua, Kabupaten Jayapura merupakan salah satu kabupaten di Provinsi Papua yang mampu melaksanakan pembangunan dengan baik. Sesuai dengan potensi yang dimiliki oleh Kabupaten Jayapura, baik sebelum maupun sesudah adanya pemekaran wilayah, sektor pertanian merupakan sektor utama dan berperan penting bagi pembangunan. Kriteria fisik/ lingkungan, ekonomi, dan sosial perlu diperhatikan dalam upaya pemekaran wilayah agar tidak terjadi disparitas (Khairullah \& Cahyadin, 2006). Harapan dengan adanya pemekaran wilayah ini adalah terjadi pertumbuhan ekonomi, yang indikasinya dapat dilihat dari peningkatan sektor sekunder serta tersier yang diikuti dengan menurunnya peranan sektor primer dalam PDRB, pemerataan pendapatan dan mengurangi ketimpangan pembangunan di Kabupaten Jayapura. Hal ini didukung oleh hasil penelitian Susanti (2014) mengenai pemekaran wilayah di Kabupaten Lampung Utara bahwa pemekaran wilayah berdampak positif bagi kesejahteraan ekonomi masyarakat ditandai dengan peningkatan nilai PAD serta terjadi pula peningkatan kualitas infrastruktur. Ini dikarenakan pemekaran wilayah dapat mengurangi luas daerah dan cakupan kendali pemerintahan yang semakin sempit sehingga akan memudahkan untuk terjadi pemerataan pembangunan. Serupa dengan hasil penelitian Riadi (2009) tentang dampak pemekaran wilayah di Kabupaten Donggala bahwa pemekaran wilayah berdampak pada tingkat kesejahteraan dan kemudahan aspek layanan publik.

Dikutip dari Papua dalam angka tahun 2010 (BPS Provinsi Papua, 2010) bahwa pada tahun 2010, dengan luas wilayah Papua $317.062 \mathrm{~km}^{2}$ atau setara dengan 17,04\% dari luas Indonesia $\left(1.860 .359,67 \mathrm{~km}^{2}\right)$, dengan jumlah penduduk yang paling sedikit di Indonesia sebesar 1,19\% (2.097.482 jiwa), maka kepadatan penduduk yang ada di wilayah Papua hanya sekitar 9 jiwa $/ \mathrm{km}^{2}$. Dengan fakta ini munculah permasalahan pembangunan di Papua antara lain pertama, terjadinya ketimpangan pembangunan yang disebabkan karena persebaran penduduk yang tidak merata disebabkan daerah yang sangat luas. Kedua, terjadinya kemiskinan yang disebabkan oleh tidak adanya pemerataan pembangunan di setiap daerah Papua sedangkan pusat-pusat kegiatan pembangunan atau perekonomian hanya di daerah tertentu.

Perkembangan suatu wilayah itu sangat bergantung pada aspek ekonomi, sosial, dan infrastruktur yang tersedia pada suatu daerah. Dari ketiga aspek tersebut diharapkan bahwa kebijakan apapun yang diambil dalam pengembangan suatu wilayah, khususnya dalam kebijakan pemekaran wilayah di era otonomi daerah, sangat perlu diperhatikan. Hal ini dapat dilihat dari potensi lokal yang ada di wilayah tersebut karena akan meningkatkan ekonomi daerah tersebut. Selain itu, populasi yang terus meningkat di suatu daerah perlu diimbangi dengan ketersedian infrastruktur sehingga kesejahteraan dapat tercapai dan masyarakat mendapatkan pelayanan publik yang efektif dan efisien sebagai dasar tujuan dari pemekaran wilayah itu sendiri. Hasil penelitian Riani dan Pudjihardjo (2012) di Papua mengenai dampak pemekaran wilayah pada aspek kesejahteraan penduduk menunjukkan bahwa pemekaran wilayah hanya berpengaruh signifikan bagi penurunan angka kemiskinan di Provinsi Papua, namun tidak berpengaruh bagi pendapatan per kapita. Namun demikian, jika dibandingkan kondisi ketimpangan wilayah sebelum pemekaran wilayah di Papua, ketimpangan pembangunan menurun. Hasil penelitian tersebut belum menunjukkan dampak pemekaran wilayah bagi aspek lainnya, seperti sosial kependudukan dan infrastruktur karena hanya menyoroti tentang dampak pemekaran wilayah bagi upaya aspek ekonomi dalam pengurangan angka kemiskinan. Untuk itu, penelitian ini bertujuan untuk mengetahui pengembangan wilayah di Kabupaten Jayapura sebelum dan setelah pemekaran dengan pembatasan pada aspek ekonomi, sosial kependudukan, dan infrastruktur. 


\section{Karakteristik Pengembangan Wilayah Sebelum dan Sesudah Pemekaran Kabupaten Jayapura}

\section{Metode Penelitian}

Penelitian dilakukan dengan menggunakan metode kuantitatif. Metode ini digunakan untuk mengkaji pengaruh pemekaran wilayah di era otonomi daerah terhadap pengembangan wilayah di Kabupaten Jayapura. Penelitian dilakukan dalam interval waktu tahun 2002 hingga 2012, dimana tahun 2002 merefleksikan kondisi Kabupaten Jayapura sebelum pemekaran dan tahun 2012 menggambarkan kondisi setelah pemekaran. Pengumpulan data dilakukan menggunakan metode pengumpulan data primer melalui wawancara dan observasi lapangan terkait dengan isu pemekaran wilayah di Kabupaten Jayapura serta metode pengumpulan data sekunder melalui kajian literatur dan survey instansi ke BPS, Bappeda, dan Dinas Pekerjaan Umum Kabupaten Jayapura. Sumber data utama pada penelitian adalah sumber data sekunder yang didapatkan dari hasil survey instansi, namun hasil penelitian akan diverifikasi melalui wawancara ke instansi terkait, seperti Bappeda dan Dinas Pekerjaan Umum dan observasi lapangan. Teknik analisis menggunakan analisis komparatif dengan membandingkan hasil pengembangan wilayah sebelum pemekaran wilayah dan pengembangan wilayah setelah adanya pemekaran wilayah yang ditinjau dari aspek ekonomi, aspek sosial kependudukan, dan aspek infrastruktur sebagai fungsi pelayanan bagi masyarakat. Variabel pada aspek ekonomi mencakup PDRB Kabupaten Jayapura, jumlah penduduk miskin, jumlah pengangguran, dan tingkat pendapatan masyarakat (Jhingan, 1992). Variabel untuk aspek sosial kependudukan mencakup kondisi kesehatan meliputi angka kelahiran dan kematian bayi, Indeks Pembangunan Manusia (IPM) dan angka harapan hidup; kondisi pendidikan meliputi angka partisipasi sekolah, jumlah guru dan murid; dan kondisi jumlah kepadatan penduduk (Hill \& Williams, 1985; Margareth \& Midgley, 1982). Aspek infrastruktur meliputi ketersediaan sarana pendidikan dan keseharan (Grigg dalam Kodoatie, 2005).

\section{Gambaran Umum}

Kabupaten Jayapura adalah kawasan yang terletak diantara 139015' BB - 140045' BT dan $2^{0} 15^{\prime}$ LU - 3045' LS. Luas wilayah administrasi Kabupaten Jayapura adalah 17.516,6 $\mathrm{km}^{2}$. Secara administrasi Kabupaten Jayapura memiliki batas-batas wilayah antara lain:

Sebelah Utara : Kabupaten Sarmi dan Samudra Pasifik;

Sebelah Selatan : Kabupaten Pegunungan Bintang dan Tolikara;

Sebelah Barat : Kabupaten Sarmi;

Sebelah Timur : Kabupaten Keerom dan Kota Jayapura.

Wilayah Kabupaten Jayapura mengalami perubahan ketika pemerintah mengesahkan UU No. 26/2002 tentang pembentukan kabupaten baru, di antaranya Kabupaten Jayapura. Kabupaten ini mengalami pemekaran menjadi tiga wilayah, yaitu Sarmi, Keerom, dan Jayapura sebagai kabupaten induk. Setelah pemekaran wilayah, luas wilayah kabupaten induk berkurang sekitar $72 \%$ dari luas semula $61.493 \mathrm{~km}^{2}$ sehingga saat ini Kabupaten Jayapura mempunyai wilayah seluas $17.516 \mathrm{~km}^{2}$. Kabupaten Jayapura terdiri dari 11 kecamatan/ distrik. Dengan pemekaran kabupaten, ibukota Kabupaten Jayapura adalah di Distrik Sentani. Tabel 1 menyajikan nama distrik dan luas wilayah masing-masing distrik di Kabupaten Jayapura sebelum dan setelah pemekaran. Distrik Kaureh merupakan distrik terluas di Kabupaten Jayapura dengan luas 4.537,9 $\mathrm{km}^{2}$ atau sekitar 24,88\% dari luas keseluruhan Kabupaten Jayapura. Sedangkan kabupaten terkecil adalah Sentani Barat dengan luas sekitar 129,2 $\mathrm{km}^{2}$ atau sekitar 0,47\% dari luas Kabupaten Jayapura. 
Tabel 1. Distrik Di Kabupaten Jayapura Sebelum dan Setelah Pemekaran

\begin{tabular}{|c|c|c|c|c|}
\hline $\begin{array}{c}\text { Nama Distrik } \\
\text { Tahun } 2002 \\
\end{array}$ & $\begin{array}{c}\text { Nama Distrik } \\
\text { Tahun } 2012 \\
\end{array}$ & $\begin{array}{c}\text { Luas } \\
\left(\mathbf{K m}^{2}\right)\end{array}$ & $\begin{array}{c}\text { Luas } \\
\left(\mathbf{K m}^{2}\right)\end{array}$ & Keterangan \\
\hline Sentani Timur & Sentani Timur & 484,22 & \multirow{4}{*}{871,58} & \\
\hline \multirow{3}{*}{ Sentani } & Sentani & 225,97 & & Merupakan Distrik Pemekaran dari \\
\hline & Ebungfau & 387,36 & & $\begin{array}{l}\text { Distrik Sentani Berdasarkan Perda Kab. } \\
\text { Jayapura No.12 Tahun } 2003\end{array}$ \\
\hline & Waibu & 258,25 & & $\begin{array}{l}\text { Merupakan Distrik Pemekaran dari } \\
\text { Distrik Sentani Berdasarkan Perda Kab. } \\
\text { Jayapura No.12 Tahun } 2003\end{array}$ \\
\hline Sentani Barat & Sentani Barat & $\begin{array}{l}129,13 \\
479,43\end{array}$ & & \\
\hline \multirow[t]{2}{*}{ Demta } & Yokari & 519,44 & 998,87 & $\begin{array}{l}\text { Merupakan Distrik Pemekaran dari } \\
\text { Distrik Demta Berdasarkan Perda Kab.. } \\
\text { Jayapura No. } 2 \text { Tahun } 2006\end{array}$ \\
\hline & Depapre & 404,28 & \multirow[b]{2}{*}{871,58} & \\
\hline Depapre & Ravenirara & 467,3 & & $\begin{array}{l}\text { Merupakan Distrik Pemekaran dari } \\
\text { Distrik Depapre Berdasarkan Perda } \\
\text { Kab. Jayapura No. } 2 \text { Tahun } 2006\end{array}$ \\
\hline Kemtuk & $\begin{array}{l}\text { Kemtuk } \\
\text { Kemtuk Gresi }\end{array}$ & $\begin{array}{l}258,25 \\
382,35\end{array}$ & \multirow[b]{2}{*}{526,21} & \\
\hline Kemtuk Gresi & Gresi Selatan & 143,86 & & $\begin{array}{l}\text { Merupakan Distrik Pemekaran dari } \\
\text { Distrik Kemtuk Gresi Berdasarkan } \\
\text { Perda Kab. Jayapura No. } 2 \text { Tahun } 2006\end{array}$ \\
\hline Nimboran & Namblong & 193,69 & 903,88 & $\begin{array}{l}\text { Merupakan Distrik Pemekaran dari } \\
\text { Distrik Nimboran Berdasarkan Perda } \\
\text { Kab. Jayapura No.12 Tahun } 2003\end{array}$ \\
\hline Nimbokrang & Nimbokrang & 774,75 & & \\
\hline Unurum Guay & $\begin{array}{l}\text { Unurum Guay } \\
\text { Kaureh }\end{array}$ & $\begin{array}{l}3131,29 \\
4357,98\end{array}$ & \multirow{3}{*}{8564,2} & \\
\hline \multirow[t]{2}{*}{ Kaureh } & Yapsi & 1291,25 & & $\begin{array}{l}\text { Merupakan Distrik Pemekaran dari } \\
\text { Distrik Kaureh Berdasarkan Perda Kab. } \\
\text { Jayapura No.12 Tahun } 2003\end{array}$ \\
\hline & Airu & 2915,01 & & $\begin{array}{l}\text { Merupakan Distrik Pemekaran dari } \\
\text { Distrik Kaureh Berdasarkan Perda Kab. } \\
\text { Jayapura No.12 Tahun } 2003\end{array}$ \\
\hline
\end{tabular}

\section{Hasil dan Pembahasan}

Pengaruh pemekaran wilayah di Kabupaten Jayapura dapat kita lihat dari segi makro maupun mikro. Secara makro pemekaran wilayah di Kabupaten Jayapura, apabila dibandingkan dengan Provinsi Papua sebagai benchmark atau tolak ukurnya, telah mengalami peningkatan atau perkembangan terutama dalam aspek ekonomi maupun sosial kependudukan. Hal ini dapat dilihat dari kondisi makro Kabupaten Jayapura yang memiliki kecenderungan positif. Jika dibandingkan dengan Provinsi Papua, Kabupaten Jayapura memiliki kondisi yang lebih baik karena pemekaran yang terjadi dapat dikatakan berhasil atau mampu memberikan pengaruh yang positif terhadap perkembangan wilayah Kabupaten Jayapura. Tabel 2 menunjukkan komparasi kondisi aspek ekonomi, sosial kependudukan, dan infrastruktur di Kabupaten Jayapura setelah pemekaran dibandingkan Provinsi Papua. 
Tabel 2. Perkembangan Kabupaten Japyapura Setelah Pemekaran Dibandingkan Provinsi Papua

\begin{tabular}{|c|c|c|c|c|c|}
\hline \multirow{2}{*}{ No } & \multirow{2}{*}{ Variabel } & \multicolumn{2}{|c|}{ Nilai } & \multirow{2}{*}{ Tolak Ukur } & \multirow{2}{*}{$\begin{array}{l}\text { Kecenderungan } \\
\text { Perkembangan }\end{array}$} \\
\hline & & 2002 & 2012 & & \\
\hline \multicolumn{6}{|c|}{ Aspek Ekonomi } \\
\hline 1 & PDRB per sektor & Rp 443.326,90 & Rp 1.797.501,35 & & Positif \\
\hline 2 & PDRB per kapita & $\operatorname{Rp} 2.401 .437,09$ & $\operatorname{Rp} 7.807 .953,46$ & $\operatorname{Rp} 6.816 .876,39$ & Positif \\
\hline \multicolumn{6}{|c|}{ Aspek Sosial Kependudukan } \\
\hline 1 & IPM & 64,9 & 70,25 & 65,86 & Positif \\
\hline 2 & $\begin{array}{l}\text { Angka harapan } \\
\text { hidup }\end{array}$ & 65,20 & 67,28 & 69,12 & Negatif \\
\hline 3 & $\begin{array}{l}\text { Angka melek } \\
\text { huruf }\end{array}$ & 88,8 & 92,32 & 75,83 & Positif \\
\hline 4 & $\begin{array}{l}\text { Rata-rata lama } \\
\text { sekolah }\end{array}$ & 6,6 & 8,0 & 6,8 & Positif \\
\hline
\end{tabular}

Secara makro perkembangan Kabupaten Jayapura memiliki kecenderungan yang positif. Ini menunjukkan bahwa kondisi Kabupaten Jayapura bila dibandingkan dengan Provinsi Papua sebagai tolak ukurnya itu lebih baik, berarti pemekaran yang dilakukan bisa dikatakan berhasil atau meberikan pengaruh yang positif terhadap perkembangan wilayah Kabupaten Jayapura. Namun, perlu diperhatikan secara khusus, walaupun hampir semua nilai variabel Kabupaten Jayapura berada di atas Provinsi Papua, pada variabel angka harapan hidup mengalami peningkatan tapi masih berada dibawah Provinsi Papua. Hal ini harus diperhatikan oleh pemerintah Kabupaten Jayapura.

Jika dibandingkan secara mikro atau dibandingkan dengan kondisi antar kecamatan di Kabupaten Jayapura, kecenderungan perkembangan aspek ekonomi, sosialkependudukan dan infrastruktur setelah pemekaran di Kabupaten Jayapura adalah positif. Hal ini menunjukan bahwa dari segi jumlah atau kuantitif mengalami peningkatan. Hanya pada aspek ekonomi di variabel jumlah angka pengangguran kecenderungan perkembangannya negatif yang mengindikasikan bahwa pemekaran di Kabupaten Jayapura belum memberikaan pengaruh. Hal ini dilihat dengan semakin bertambahnya penduduk yang menganggur. Pada aspek sosial-kependudukan di variabel rasio guru terhadap murid kecendeerungan perkembangannya negative, dimana jumlah guru yang mengajar di Kabupaten Jayapura tidak sebanding dengan jumlah murid. Kecenderungan perkembangan di Kabupaten Jayapura setelah pemekaran terlihat di Tabel 3.

Tabel 3. Kecenderungan Perkembangan Aspek Mikro Setelah Pemekaran

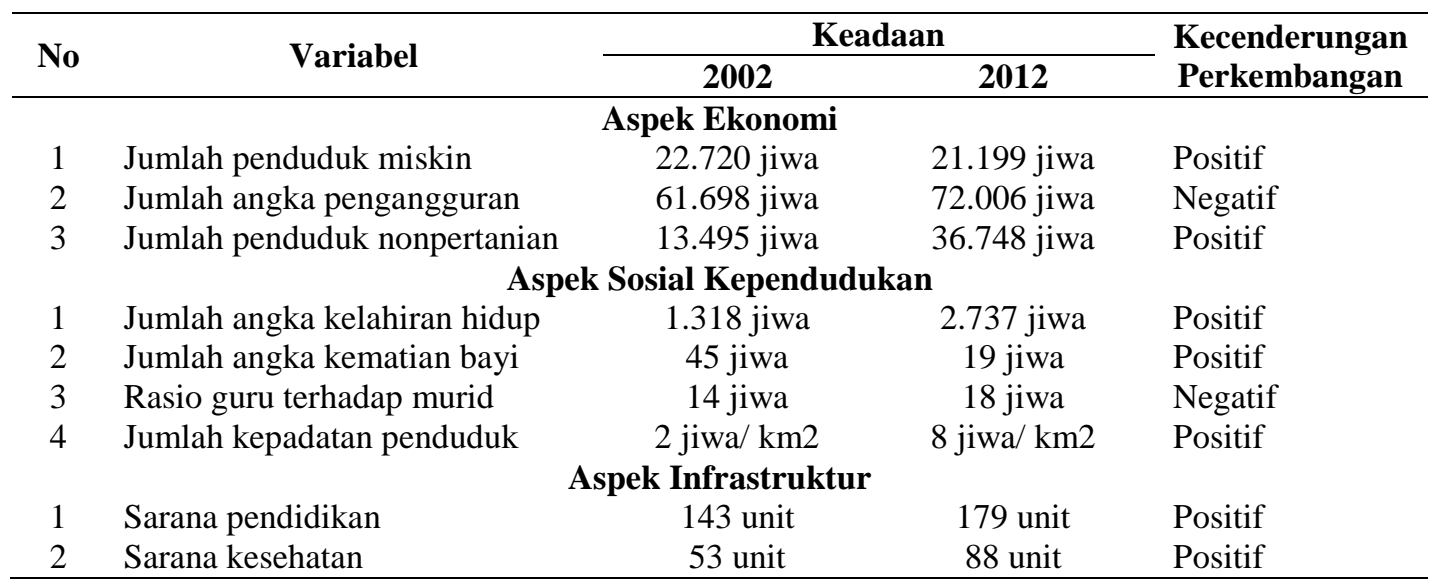


Apabila diidentifikasi secara mikro, aspek ekonomi, aspek sosial kependudukan dan aspek infrastruktur mengalami kecenderungan perkembangan yang positif. Pertama, pada aspek ekonomi, hanya pada variabel angka pengangguran saja yang kecenderungannya negatif. Ini menunjukkan bahwa adanya pemekaran wilayah tersebut banyak penduduk dari luar Kabupaten Jayapura yang datang tetapi lapangan pekerjaanya belum mencukupi. Senada dengan yang dikatakan Jhingan (1992: 26-27) bahwa potensi pertumbuhan penduduk yang tinggi umumnya terjadi di negara berkembang dan akan meningkatkan jumlah tenaga kerjanya, pengangguran membengkak seiring dengan urbanisasi dan strata pendidikan di masyarakat yang tidak diiringi oleh pertambahan sektor industri.

Bila dilihat pada aspek pelayanan publik hanya pada variabel rasio guru terhadap murid yang kecenderungannya negatif artinya pada tahun 2002 terdapat 1 orang guru mengajar 14 siswa, sedangkan pada tahun 2012 terdapat 1 orang guru mengajar 18 siswa. Dapat disimpulkan bahwa pendidikan merupakan bentuk investasi yang sangat penting bagi pengembangan suatu wilayah. Senada dengan Galbraith (dalam Jhingan, 1992: 550) pendidikan menjadi suatu bentuk investasi yang sangat produktif. Selain itu pada angka bayi lahir mati kecenderungannya positif hal ini menunjukkan semakin meningkatya kualitas kesehatan, hal ini senada dengan yang dikatakan oleh Jhingan (1992: 551) untuk meningkatkan efisiensi dan produktivitas, kesehatan masyarakat harus diperbaiki.

Bila dilihat pada aspek infrastruktur kecenderungan perkembangannya positif. Artinya sarana yang tersedia setelah ada pemekaran itu semakin banyak jumlahnya dalam hal ini sarana pendidikan dan kesehatan. Dapat disimpulkan bahwa pemekaran memberikan pengaruh terhadap ketersediaan infrastruktur sebagaimana diungkapkan oleh Susanti (2014) dan Riadi (2009). Infrastruktur berpengaruh signifikan bagi tercapainya pemerataan pembangunan pada daerah pemekaran karena berpengaruh terhadap iklim investasi (Yuliadi, 2012).

Jika dikomparasikan antara kondisi sebelum dan setelah perkembangan wilayah secara mikro (komparasi antar kecamatan di Kabupaten Jayapura), hasil komparasi mengenai aspek ekonomi, sosial kependudukan, dan ekonomi yang diidentifikasi menggunakan 9 variabel terjabarkan di Tabel 4. Dari hasil perkembangan akan diklasifikasikan menjadi 4 kelas, yaitu kecamatan mana yang terpengaruh tinggi, sedang, dan rendah karena adanya pemekaran dengan klasifikasi rendah $=(0-25 \%)$; sedang $(26-$ $50 \%)$; tinggi (51-75\%); sangat tinggi ( $>75 \%)$.

Pengaruh pemekaran terhadap pengembangan wilayah di Kabupaten Jayapura terbagi dalam 4 kategori, yaitu pengaruh sangat tinggi, tinggi, sedang dan rendah. Gambar 1 menyajikan mengenai peta pengaruh pengembangan wilayah Kabupaten Jayapura setelah pemekaran. Dari peta 1 tersebut terlihat kualifikasi tingkat pengaruh pada daerahdaerah di Kabupaten Jayapura setelah pemekaran terjadi. Adapun pengaruh pemekaran terhadap pengembangan wilayah di Kabupaten Jayapura secara umum dapat dijelaskan:

1. Kondisi pengembangan wilayah dengan pengaruh sedang terjadi di Kecamatan Kaureh, Kecamatan Depapre, dan Kecamatan Sentani Barat. Pada Kecamatan Kaureh terjadi karena kondisi geografis berupa daerah pegunungan dan terletak jauh dengan Ibukota Kabupaten Jayapura dapat diartikan belum mampu mengoptimalkan jangkauan pelayanan antar kecamatan. Padahal pemekaran wilayah harus mampu mengoptimalkan jangkauan pelayanan ke masyarakatnya sebagaimana dikatakan Rasyid (2007). Sedangkan pada Kecamatan Depapre dan Kecamatan Sentani Barat jangkauan pelayanan sudah optimal namun belum memiliki ketersediaan infrastruktur. Padahal keberhasilan pengembangan wilayah dapat diukur dari ketersediaan, kecukupan serta kemampuan sarana dan prasarana yang mempunyai peranan penting terhadap peningkatan kesejahteraan masyarakat. Seperti yang dikatakan oleh Grigg (dalam Kodoatie, 2005) bahwa infrastruktur merujuk pada sistem fisik yang 
menyediakan fasilitas publik yang lain yang dibutuhkan untuk memenuhi kebutuhan dasar manusia dalam lingkup sosial dan ekonomi.

2. Kondisi pengembangan wilayah dengan pengaruh tinggi terjadi di Kecamatan Nimboran, Unurum Guay, Demta, dan Sentani Timur. Dapat disimpulkan terjadi pengaruh yang tinggi karena di Kecamatan Nimboran dan Demta belum memiliki layanan infrastruktur yang optimal, seperti sarana kesehatan dan pendidikan. Padahal motif dari pemekaran wilayah menurut World Bank (2001) mencakup efektifitas/efisiensi pelayanan kepada masyarakat. Meskipun penduduk miskin dan angka penganggurannya berkurang. Di Kecamatan Unurum Guay terjadi sebaliknya, dimana terjadi peningkatan ketersediaan infrastruktur (sarana kesehatan dan pendidikan), namun penduduk miskin dan angka penganggurannya meningkat. Sehingga keberhasilan pengembangan wilayah memliki keterkaitan yang linear dengan aspek ekonomi, sosial kependudukan dan infrastruktur. Sejalan dengan Khairullah \& Cahyadin (2006) yang mengungkapkan bahwa pemekaran wilayah kabupaten baru sebagai upaya meningkatkan kualitas dan intensitas pelayanan pada masyarakat;

3. Kecamatan dengan kecenderungan perkembangan sangat tinggi terjadi hubungan yang linier antara aspek ekonomi, sosial kependudukan dan infrastruktur, pengembangan wilayah menurut Schumpeter (dalam Jhingan, 1992: 6) adalah perubahan spontan dan terputus-putus dalam keadaan stasioner yang senantiasa mengubah dan mengganti situasi keseimbangan yang ada sebelumnya, dimana dapat diasumsikan bahwa indikator pengembangan wilayah dapat ditinjau dari perkembangan aspek ekonomi, sosial dan infrastruktur terkecuali Kecamatan Sentani. Terlepas dari kondisi penduduk miskin dan angka pengangguran yang tinggi di Kecamatan Sentani, persentase penduduk non pertanian mengalami peningkatan yang signifikan dibandingkan dengan kecamatan lainnya. Senada dengan yang dikatakan dengan Kutnets dalam Jhingan (1983: 72-82) laju pertumbuhan struktural yang tinggi ditandai dengan pengalihan kegiatan pertanian ke nonpertanian.

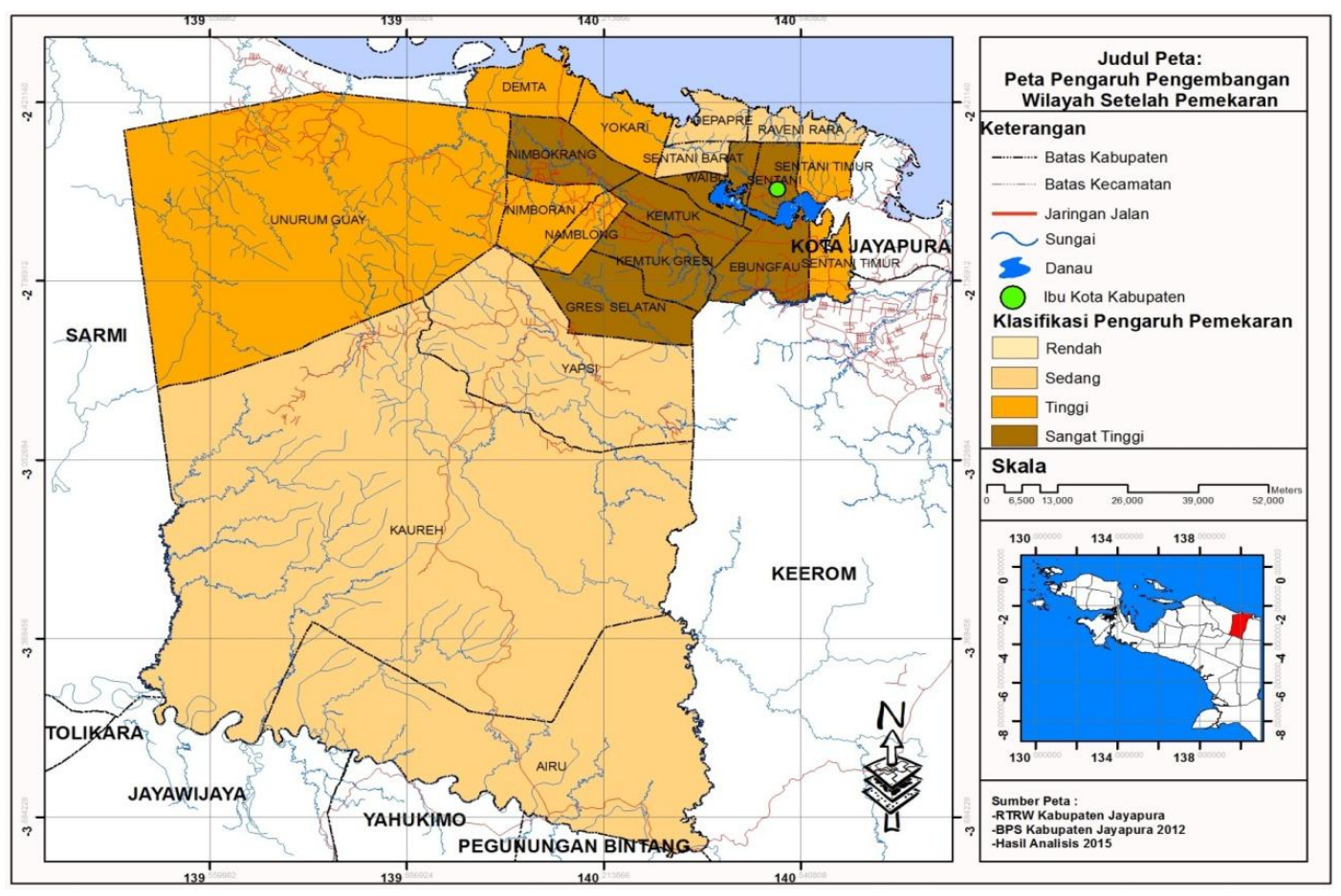

Gambar 1. Peta Pengaruh Pengembangan Wilayah Kabupaten Jayapura Setelah Pemekaran 


\section{Tabel 4. Persentase Perkembangan Masing-Masing Variabel di Masing-Masing Kecamatan di Kabupaten Jayapura Sebelum dan Setelah Pemekaran}

\begin{tabular}{|c|c|c|c|c|c|c|c|c|c|c|}
\hline Kecamatan & $\begin{array}{c}\text { Penduduk } \\
\text { miskin }\end{array}$ & $\begin{array}{c}\text { Angka } \\
\text { pengangguran }\end{array}$ & $\begin{array}{c}\text { Penduduk } \\
\text { nonpertanian }\end{array}$ & $\begin{array}{l}\text { Bayi } \\
\text { lahir } \\
\text { hidup }\end{array}$ & $\begin{array}{l}\text { Bayi } \\
\text { lahir } \\
\text { mati }\end{array}$ & $\begin{array}{l}\text { Rasio guru } \\
\text { terhadap } \\
\text { murid }\end{array}$ & $\begin{array}{l}\text { Kepadatan } \\
\text { penduduk }\end{array}$ & $\begin{array}{c}\text { Jumlah } \\
\text { sarana } \\
\text { kesehatan }\end{array}$ & $\begin{array}{c}\text { Jumlah } \\
\text { sarana } \\
\text { pendidikan }\end{array}$ & $\begin{array}{c}\text { Perkembangan } \\
\text { positif dari total } \\
\text { variabel }(\%)\end{array}$ \\
\hline Kaureh & - & + & - & + & + & + & - & - & - & 44,44 \\
\hline Kemtuk & + & + & - & + & + & + & + & + & + & 77,78 \\
\hline $\begin{array}{l}\text { Kemtuk } \\
\text { Gresi }\end{array}$ & + & + & - & + & + & + & + & - & + & 77,78 \\
\hline Nimboran & + & + & - & - & + & + & + & - & - & 55,56 \\
\hline Nimbokrang & + & + & - & + & + & + & + & + & + & 88,89 \\
\hline $\begin{array}{l}\text { Unurum } \\
\text { Guay }\end{array}$ & - & - & + & + & + & + & - & + & + & 66,67 \\
\hline Demta & + & + & + & - & + & + & - & - & - & 55,56 \\
\hline Depapre & + & + & - & - & + & + & - & - & - & 44,44 \\
\hline $\begin{array}{l}\text { Sentani } \\
\text { Barat }\end{array}$ & + & + & - & - & + & + & - & - & - & 44,44 \\
\hline Sentani & - & - & + & + & + & + & + & + & + & 77,78 \\
\hline $\begin{array}{l}\text { Sentani } \\
\text { Timur }\end{array}$ & + & + & - & + & - & - & - & + & + & 66,67 \\
\hline
\end{tabular}




\section{Kesimpulan}

Jika dibandingkan secara makro dengan Provinsi Papua, perkembangan Kabupaten Jayapura setelah pemekaran memiliki kecenderungan yang positif jika dari aspek ekonomi, sosial penduduk, dan infrastruktur. Jika dibandingkan secara mikro dengan kecamatankecamatan di Kabupaten Jayapura, menunjukkan bahwa belum seluruh aspek berkontribusi positif bagi pengembangan wilayah. Hal ini ditunjukkan oleh variabel pengangguran pada aspek ekonomi dan rasio guru terhadap murid pada aspek sosial kependudukan yang bernilai negatif. Namun demikian, dari segi infrastruktur telah berdampak positif bagi pembangunan. Jika dikaitkan dengan temuan Riani dan Pudjihardjo (2012) di Papua menunjukkan bahwa pemekaran wilayah di Papua secara umum belum cukup berdampak positif bagi aspek ekonomi dilihat dari kesejahteraan penduduknya. Sebagaimana di Kabupaten Jayapura bahwa angka pengangguran belum menurun. Namun, aspek infrastruktur bahwa Kabupaten Jayapura sudah berkembang ditandai dengan peningkatan ketersediaan sarana pendidikan dan kesehatan meskipun dihadapkan pada masalah rasio guru dan murid yang belum proporsional. Untuk itu, perlu digarisbawahi bahwa dalam membangun suatu wilayah pemekaran yang baru terdapat beberapa hal yang perlu diperhatikan, meliputi peningkatan sumber daya manusia terutama faktor pendidikan dan kesehatan serta penyediaan infrastruktur yang mencukupi.

\section{Daftar Pustaka}

Fisher, A. C. (1981). Natural resource and environmental economics. Cambridge: Cambrigde University Press.

Harmantyo. (2007). Pemekaran daerah dan konflik keruangan: Kebijakan otonomi daerah dan implementasinya di Indonesia. Makara, 11(1), 16-22.

Jhingan, M. L. (1992). Ekonomi pembangunan dan ekonomi perencanaan. Jakarta: Penerbit Rajawali.

Khairullah, \& Cahyadin, M. (2006). Evaluasi pemekaran wilayah di Indonesia: Studi kasus Kabupaten Lahat. Jurnal Ekonomi Pembangunan, 11(3), 261-277.

Kodoatie, R. (2005). Pengantar manajemen infrastruktur. Yogyakarta: Pustaka Pelajar.

Pemerintah Kabupaten Jayapura. (2003). Peraturan Daerah Kabupaten Jayapura Nomor 12 Tahun 2003 tentang Pembentukan Distrik Ebungfauw, Distrik Waibu, Distrik Namblong, Distrik Yapsi dan Distrik Airu. Kabupaten Jayapura: Pemerintah Kabupaten Jayapura.

Pemerintah Kabupaten Jayapura. (2006). Peraturan Daerah Nomor 2 Tahun 2006 tentang Pembentukan Distrik Raveni Rara, Distrik Gresi Selatan dan Distrik Yokari. Kabupaten Jayapura: Pemerintah Kabupaten Jayapura.

Rasyid, R. (2007). Otonomi daerah dalam negara kesatuan. Yogyakarta: Pustaka Pelajar.

Riadi, S. (2009). Analisis pemekaran wilayah dan potensi konflik di Kabupaten Donggala. Academia, 1(2), 200221.

Riani, I. A. P., \& Pudjihardjo, M. (2012). Analisis dampak pemekaran wilayah terhadap pendapatan per kapita, kemiskinan dan ketimpangan antarwilayah di Provinsi Papua. Jurnal Bumi Lestari, 12(1), 137-148.

Riyadi, D. S. (2002). Pengembangan wilayah dan otonomi daerah. Jakarta: Pusat Pengkajian Kebijakan Teknologi Pengembangan Wilayah.

Susanti. (2014). Dampak pemekaran wilayah terhadap kesejahteraan di Kabupaten Lampung Utara. Jurnal Ekonomi Pembangunan, 3(2), 249-268.

Ventauli. (2009). Mengelola dinamika politik dan sumber daya daerah. Yogyakarta: Program S2 Politik Lokal dan Otonomi Daerah UGM.

World Bank. (2001). Decentralization: rethinking government. Retrieved from World Bank E-Library website: http://elibrary.worldbank.org/doi/abs/10.1596/0195211243_Chapter5.

Yuliadi, I. (2012). Kesenjangan investasi dan evaluasi kebijakan pemekaran wilayah di Indonesia. Jurnal Ekonomi Pembangunan, 13(2), 276-287. 